\title{
Comparative study of the coagulation efficacy of Moringa Oleifera seeds extracts to alum for domestic wastewater treatment of Ain Aouda City, Morocco.
}

\author{
Naif Al-Jadabi ${ }^{1 *}$, Mohamed Laaouan ${ }^{2,3}$, Jamal Mabrouki ${ }^{1}$, Ghizlane Fattah $^{4}$, and Souad El Hajjaji ${ }^{1}$ \\ ${ }^{1}$ Laboratory of Spectroscopy, Molecular Modeling, Materials, Nanomaterials, Water and Environment (LS3MN2E-CERNE2D), \\ Department of Chemistry, Faculty of Sciences, Mohammed V University in Rabat, Avenue IbnBattouta, B.P. 1014, \\ Rabat10000, Morocco. \\ ${ }^{2}$ International Institute of Water and Sanitation, National Office of Electricity and Drinking Water (IEA-ONEE), Avenue \\ Mohamed BelHassan El Ouazzani, B.P. Rabat-Chellah 10002/ Rabat, Morocco. \\ ${ }^{3}$ Central Laboratory for water quality control, National Office of Electricity and Drinking Water (ONEE), Avenue Mohamed \\ BelHassan El Ouazzani, B.P. Rabat-Chellah 10002/ Rabat, Morocco. \\ ${ }^{4}$ Water treatment and reuse structure, Civil hydraulic and environmental engineering laboratory, Mohammadia School of \\ Engineers, Mohammed V University in Rabat, Avenue IbnSina B.P 765, Agdal-Rabat, 10090 Morocco.
}

\begin{abstract}
This research aimed to investigate the performance of seeds extract of Moringa Oleifera (MO) as an eco-friendly coagulant and an alternative practice in enhancing primary domestic wastewater effluent treatment by coagulation/flocculation, and sedimentation. The seeds of Moringa Oleifera were dried, crushed, and sieved, the content of oil was extracted with n-hexane as a solvent employing soxhlet apparatus (electro thermal) then used the residue as domestic wastewater coagulant. Jar tests were conducted for improve the primary treatment of domestic wastewater effluent from the wastewater plant of Ain Aouda city, Rabat, Morocco. For this reason, perform of coagulation tests was comparative with using aluminium sulphate (alum). Moringa Oleifera seeds extract at the optimal dose of $250 \mathrm{mg} / \mathrm{L}$ shows encouraging results, by comparison with the use of alum $(150 \mathrm{mg} / \mathrm{L})$. In reality, in terms of TSS reduction $95.5 \%$ and $96.8 \%$, while turbidity reduction $97.5 \%$ and $98.1 \%$ were obtained for MO seeds extract and alum, respectively. But, the reduction rate of COD and BOD of Alum was somewhat higher than that of MO seeds extract $81.8 \%$ and $76.8 \%$ for COD, while were $75.5 \%$ and $72 \%$ for BOD respectively. Differently from alum, observed that increase in the extract of MO seeds dosage happened a slight change in $\mathrm{pH}$ value, decrease conductivity, and three times less bulky quantity of sludge than alum. For avoiding the numerous disadvantages associated with the use of chemical coagulants, the usage of Moringa Oleifera seeds extracts is recommended.
\end{abstract}

\section{Introduction}

Among many factors, human population growth and lifestyles emerging changes influence the quality and generated quantity of municipal wastewater [1]. Worldwide, especially in middle and low-income countries, a large portion of collected domestic wastewater isn't adequately treated before its release into water bodies [2], which lead to a negative effect on the quality of drinking water and a significant public health threat [3]. In developing countries, many communities, resort to using water from streams and rivers due to the lack in the supply system of potable water, which them exposes to the risk of waterborne diseases [4].
In this context, Morocco focused on treating $60 \%$ of collected wastewater by 2020 [3]. Usually, the chemical coagulant of aluminium sulphate is broadly used in water treatment by the process of coagulation-flocculation which can be utilized as one of empowering forms [5-7]. However, the use of alum is linked with the negative environmental and human impacts; also, the generation of large volumes of sludge is very hazardous [8], [9]. Because conventional synthetic coagulants used in water treatment, have a high chemical cost, which is considered one of the essential contributors related to operational cost. Therefore, it is necessary to seek natural coagulants and locally available to reduce the

* Corresponding author: naif.naif.2017@gmail.com 
negatives impacts the synthetic coagulants on humans and the environment [10].

In recent years, focused interest on using natural coagulants that are extracted from plants [8]. Natural coagulants are used to destabilize colloidal particles, antimicrobial activity, and have heavy metal removing properties [10], [11]. M. Oleifera is one of the natural coagulants, certainly the most investigated of the 13 recognized species in the genus Moringa and effective in wastewater treatment [12]. Moringa Oleifera is the most widely used, accepted, and studied [13]. Moringa Oleifera seeds are a natural polymer that contains cationic proteins [14], are water-soluble [15]. In the recent years, Moringa Oleifera has been used as a coagulant to treat water [16]. it has strong natural coagulate and is able to remove suspension impurities from treated water by destabilizing negative colloids, aggregation followed by precipitation, and obtaining clear water [17], [2]. Depending on the initial turbidity, cationic proteins were found to reduce by $50-99.5 \%$ of water turbidity [18], comparable to commercial alum in the removal of turbidity [19]. After treatment, use seeds of M. Oleifera, the $\mathrm{pH}$ value and conductivity of the water do not significantly affect [20].

Moringa seeds do not degrade the environment further, are biodegradable, and thus are eco-friendly which giving it is a sustainable alternative, particularly in the developing world compared to other conventional chemical coagulants such as aluminium sulphate, ferric chloride [12], [1]. The use seeds extracts of Moringa Oleifera as coagulant in water treatment which has been recommended in South Asian and African countries [21]. Several studies were reported Moringa Oleifera seeds extract with distilled water was used in coagulation process to water treatment [6]. Furthermore, the method of extract of Moringa Oleifera seeds with water is the most frequent because of low cost, its easy availability, and the watersoluble nature of the protein [22]. The seeds of $\mathrm{M}$. Oleifera have also been discovered to have biologically interesting properties [23]. The major goal of this research was to explore the coagulation efficacy of extract of $M$. Oleifera seeds in comparison to commercial coagulants like aluminium sulphate (alum) in improving the quality of domestic wastewater was evaluated based on the removal of Turbidity, TSS, COD, BOD5, and $\mathrm{pH}$ which represent the main important domestic wastewater parameters by coagulation-flocculation, and sedimentation. Furthermore, this research aids support efforts for the use of natural coagulants characterize as sustainable alternatives, low-cost, and eco-friendly, and for domestic wastewater treatment in Morocco.

\section{Materials and methods \\ 2.1 The coagulants \\ 2.1.1 Moringa Oleifera seeds \\ 2.1.1.1 Powder preparation of Moringa Oleifera seeds}

The seeds husk of Moringa Oleifera removed by hand to get out the kernels and then turned into a soft powder using pistil even getting consistency a very fine [24], and sieved through $500 \mu \mathrm{m}$ to obtain uniform particle size [1], and drying in an oven for $30 \mathrm{~min}$ at $105^{\circ} \mathrm{C}$ to reduce moisture content [4], because the strong affinity of the powder to attract moisture whether when grinding or after [25]. The powder and extract of M. Oleifera seeds were prepared and then kept at room temperature [26].

\subsubsection{Extraction Procedure by Soxhlet Apparatus}

Oil extraction is carried out using soxhlet apparatus (electro-thermal) at $70^{\circ} \mathrm{C}$. Around $100 \mathrm{~g}$ of the seeds powder of Moringa Oleifera mixed with $500 \mathrm{~mL}$ of hexane as solvent. This process continued for $4 \mathrm{~h}$, until the solvent has become colourless, indicating that total oil extraction has been achieved. After that the solvent was left to condense and then separate the solvent from the oil by rotary evaporator while the remaining portion of $M$. Oleifera seeds cake after dried at room temperature was used in this study.

\subsubsection{Extract preparation of Moringa Oleifera Seeds}

Five gram of the powder was added to $100 \mathrm{ml}$ of doubled distilled water and mixed for 30 minutes using a stirrer [27], until a uniform solution and the extract was then passed through a muslin cloth [28]. This solution is recommended to be freshly prepared when used in water treatment to avoid coagulant activity decrease [2], [29]. In order to avoid the viscosity and $\mathrm{pH}$ changes is recommended its store in a cool place with a maximum temperature of $20^{\circ} \mathrm{C}$ [26].

\subsubsection{Alum $\left(\mathrm{Al}_{2}\left(\mathrm{SO}_{4}\right)_{3} .18 \mathrm{H}_{2} \mathrm{O}\right)_{(\mathrm{s})}$}

Aluminium sulphate $\mathrm{Al}_{2}\left(\mathrm{SO}_{4}\right)_{3} \cdot 18 \mathrm{H}_{2} \mathrm{O}_{(\mathrm{s})}$ with the purity of between $16-17 \%$. The alum solution was prepared by dissolution of the accurately weighed quantity of this compound in distilled water (ultrapure) at a $5 \%$ concentration (w/w).

\subsection{Coagulation-flocculation sedimentation process}

and

The process of coagulation-flocculation was performed used jar test (GPB FLC-Didatec, France) using six 1L beakers filled to the $500 \mathrm{~mL}$ of domestic wastewater 
samples to each test run. The doses of coagulants (Moringa Oleifera seeds extract and alum) were (50, $100,150,200,250,300 \mathrm{mg} / \mathrm{L})$, which were added on the six 1L beakers filled with $500 \mathrm{ml}$ of the studied sample. The tests were carried out in two separate stages, with the same operating conditions. The first stage was conducted with alum alone, and the second one was done using extract of Moringa Oleifera seeds, alone too. The mixture underwent a blending rapid of $180 \mathrm{rpm}$ for $2 \mathrm{~min}$ and the time of slow blending is 20 min with the speed of mixing of $40 \mathrm{rpm}$, and settles time for $30 \mathrm{~min}$. After the settling process, the supernatant (top layer) of treated effluents were sampled to analyse the studied parameters. The removal efficiency of this process was based on the removal percentage of turbidity, TSS, COD, and BOD5 between the initial domestic effluent and the effluent after treatment with alum and MOSE, following Equation:

\% Removal efficiency $=\frac{C_{i}-C_{f}}{C_{i}}$ Where, $\left(C_{i}\right)$ initial, $\left(C_{f}\right)$ final concentration for each parameter.

\section{Results and Discussion}

\subsection{Wastewater Characterisation}

Table 1. Shows the characteristics of the raw domestic wastewater, Moroccan standards (MS) for effluent discharge.

\begin{tabular}{|l|c|c|c|}
\hline Parameters & Units & $\begin{array}{c}\text { True } \\
\text { value }\end{array}$ & $\begin{array}{c}\text { MS values for } \\
\text { Effluent }\end{array}$ \\
\hline Temperature & ${ }^{\circ} \mathrm{C}$ & 20.5 & $<30$ \\
\hline $\mathrm{pH}$ & - & 8.19 & $6.5-8.5$ \\
\hline Conductivity & $\mu \mathrm{S} / \mathrm{cm}$ & 2200 & 2700 \\
\hline Turbidity & $\mathrm{NTU}$ & 121 & $<5$ \\
\hline $\mathrm{TSS}$ & $\mathrm{mg} / \mathrm{L}$ & 220 & 150 \\
\hline $\mathrm{COD}$ & $\mathrm{mg} / \mathrm{L}$ & 340 & 250 \\
\hline $\mathrm{BOD} 5$ & $\mathrm{mg} / \mathrm{L}$ & 150 & 120 \\
\hline $\mathrm{TP}$ & $\mathrm{mg} / \mathrm{L}$ & 5.35 & 10 \\
\hline $\mathrm{NO}_{3}{ }^{-}$ & $\mathrm{mg} / \mathrm{L}$ & $<1$ & - \\
\hline $\mathrm{NO}_{2}{ }^{-}$ & $\mathrm{mg} / \mathrm{L}$ & $<0.5$ & - \\
\hline $\mathrm{NH}_{4}{ }^{+}$ & $\mathrm{mg} / \mathrm{L}$ & 23.5 & 0.5 \\
\hline
\end{tabular}

\section{$3.2 \mathrm{pH}$ and conductivity variation}

The addition of alum as a coagulant lowered the treated sample $\mathrm{pH}$ from 8.19 to 7.62 at an optimum dose $(150 \mathrm{mg} / \mathrm{L})$ while the seeds extract water reduced to $\mathrm{pH}$ 7.65 at an optimum dose $(250 \mathrm{mg} / \mathrm{L})$. As seen in Table 2 , it can be observed that Moringa Oleifera seeds extract does not significant impact on $\mathrm{pH}$ value after the treatment [15]. On the other hand, added alum led to higher $\mathrm{pH}$ decreases than Moringa Oleifera seeds extract due to the $\mathrm{H}^{+}$proton release when the doses increase [2]. Moreover, it can be observed that the treatment with Moringa Oleifera seeds extracts decrease the conductivity while the treatment with alum increase in the conductivity value [2], [30].

Table 2. $\mathrm{pH}$ and conductivity variation after treatment with alum and MOSE

\begin{tabular}{|c|c|c|c|c|}
\hline \multirow{2}{*}{$\begin{array}{c}\text { Coagulant } \\
\text { dosage }\end{array}$} & \multicolumn{2}{|c|}{$\mathrm{pH}$} & \multicolumn{2}{c|}{$\begin{array}{c}\text { Conductivity } \\
(\mu \mathrm{S} / \mathrm{cm})\end{array}$} \\
\cline { 2 - 5 } & alum & MOSE & alum & MOSE \\
\hline 0 & 8.19 & 8.19 & 2200 & 2200 \\
\hline 50 & 7.95 & 8 & 2280 & 2170 \\
\hline 100 & 7.75 & 7.9 & 2330 & 2140 \\
\hline 150 & 7.62 & 7.8 & 2370 & 2090 \\
\hline 200 & 7.55 & 7.73 & 2410 & 2070 \\
\hline 250 & 7.42 & 7.65 & 2430 & 2050 \\
\hline 300 & 7.3 & 7.59 & 2450 & 2020 \\
\hline
\end{tabular}

\subsection{Turbidity and TSS removal}

The removal of turbidity and TSS at the optimal dosages of MOSE (250 mg/L) and alum (150 mg/L) as shown in (Fig.1 (a-b). For the initial turbidity of 121 NTU, the treatment of coagulation-flocculation was able to remove $98.1 \%$,

$97.5 \%$ of turbidity when applied with alum and MOSE, respectively. Whereas an initial TSS of $220 \mathrm{mg} / \mathrm{L}$ was removed of $95.5 \%, 96.8 \%$ of TSS when applied with MOSE and alum, respectively.
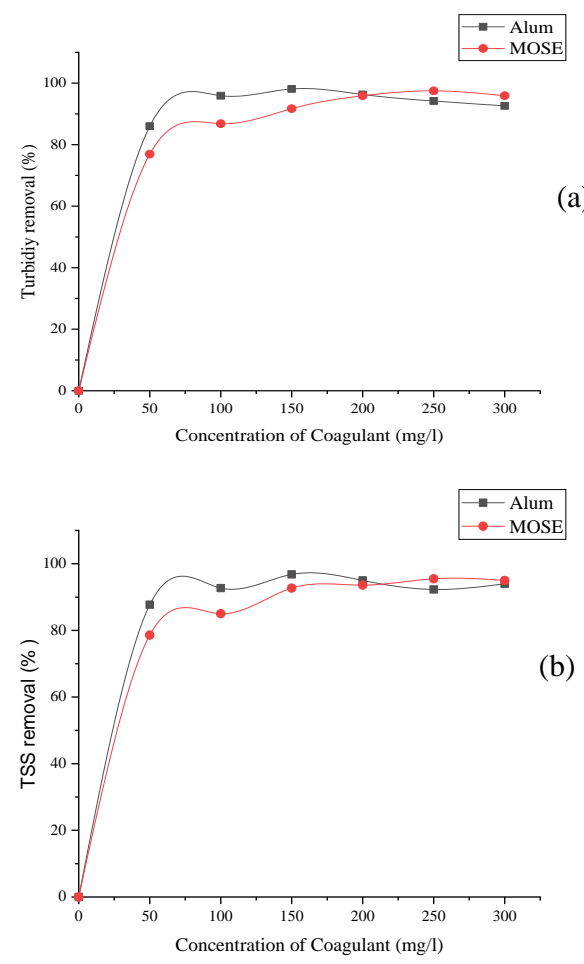

Fig.1. Effect of alum and MOSE: Turbidity removal (a); TSS removal (b). 


\subsection{COD and BOD removal}

COD and BOD removal rate after coagulationflocculation treatment is shown in Fig. 2 (a-b). Use of alum and MOSE provided around $81.8 \%, 76.8 \%$ of removal of COD, whereas the BOD removal efficiency reached $75.5 \%, 72 \%$ with optimum dosage from alum and MOSE, respectively.
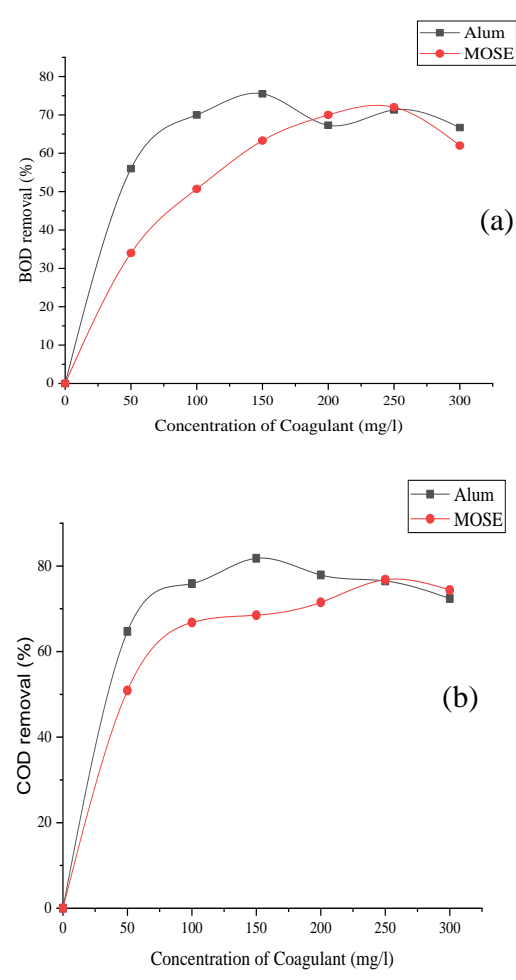

Fig.2. Effect of alum and MOSE: COD removal (a); BOD removal (b)

\subsection{Sludge volume}

The sludge volume after the treatment with Moringa Oleifera seeds extract (MOSE), and alum is presented in Table 3. The sludge volume generated from a treatment MOSE was 3 times lower than the volume by an alum-treated sample [2], [15].

Table 3. Comparison of sludge volume ratio after the treatment with MOSE and alum.

\begin{tabular}{|c|c|}
\hline Coagulant dosage & Volume ratio $(\mathrm{ml} / \mathrm{l})$ \\
\hline MOSE $-250 \mathrm{mg} / \mathrm{L}$ & 8 \\
\hline Alum $-150 \mathrm{mg} / \mathrm{L}$ & 24 \\
\hline
\end{tabular}

\subsection{Characterization of Moringa Oleifera seed extract}

The SEM image (at 500x and 1000x) of M. Oleifera seeds extract (MOSE) used as a coagulant in this study coagulant as seen in Fig. 3(a-b). Also, as can be observed in Fig. 3 the surface high heterogeneity and relatively porous. Because the spaces available have a large internal surface area, they may aid the increased availability from active sites of adsorption and which makes it's an excellent adsorbent material [31], [32].
Also, the presence of the crevices and protein components of the seeds, which makes this structure facilitates the ions absorption process [4]. On the MOSE irregular forms can be seen as compatible with bio-based materials [32], [33]. These are essential characteristics of a coagulant in terms of colloidal particle adsorption, which promotes particle sedimentation. Coagulants that contain fibres or threads when are added to the treated sample can adhere to several colloids which led to trapping them and binding them together in the bridging coagulation process [34].

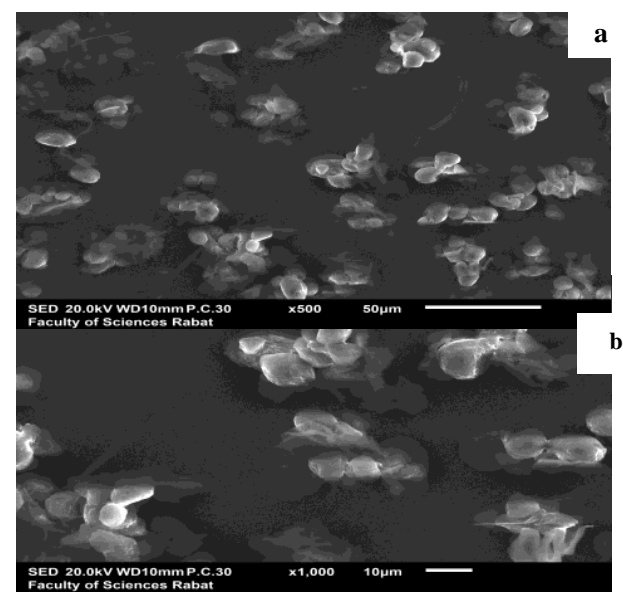

Fig. 3. Images of Moringa Oleifera seeds extract taken with a scanning electron microscope (SEM). (a) low magnification ( x500), (b) high magnification ( x1000)

\subsection{Comparison between coagulants alum and MOSE}

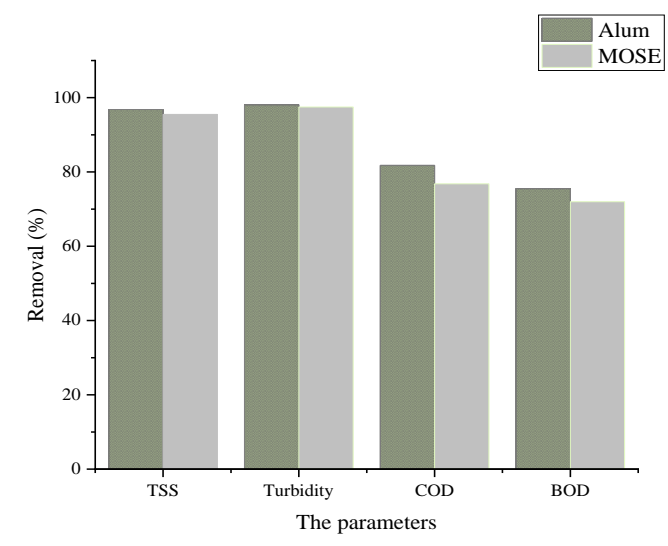

Fig.4. Comparison of removal efficiency of TSS, turbidity, COD, and BOD.

This section shows the efficiency comparison of both coagulants for removing TSS, turbidity, COD, BOD of domestic wastewater. For this purpose, domestic wastewater with an initial TSS of $220 \mathrm{mg} / \mathrm{L}$, turbidity of $121 \mathrm{NTU}$, COD of $340 \mathrm{mg} / \mathrm{L}$, and BOD $150 \mathrm{mg} / \mathrm{L}$ was used for both coagulants. Fig. 4. Shows the results obtained for each coagulant at its optimum dosage condition for all studied parameters removal (alum: concentration of $150 \mathrm{mg} / \mathrm{L}$ and MOSE: concentration of $250 \mathrm{mg} / \mathrm{L}$ ). The TSS and turbidity reduction using 
alum was slightly higher, $96.8 \%, 98.1 \%$, than Moringa Oleifera seed extract, $95.5 \%, 97.5 \%$. In terms of COD and BOD reduction $81.8 \%, 75.5 \%$ were obtained for alum while reach to $76.8 \%, 72 \%$ for Moringa Oleifera seed extract, respectively. The literature reports on the efficacy of Moringa Oleifera seeds compared to conventional coagulants provided conflicting comparisons [4]. Despite a lot of research reports show that conventional coagulants have higher coagulation efficiency compared to seeds powder of Moringa Oleifera. However, Moringa Oleifera seeds coagulation has advantages over alum coagulation, such as posttreatment can be avoided for $\mathrm{pH}$ adjustment [35]. Moringa Oleifera is also a natural resource is an easy availability, eco-friendly, non-toxic, biodegradable; thus, the use of Moringa Oleifera allows avoiding many adverse effects of conventional coagulants such as alum.

\section{CONCLUSION}

The overall goal of this research is to investigate the use potential of Moringa Oleifera seeds as a natural coagulant and eco-friendly for domestic wastewater treatment. After extracting the oil from the Moringa Oleifera seeds, component of the active coagulation was extracted using distilled water. Samples of the domestic wastewater were taken from the domestic wastewater plant (WWTP) of Ain Aouda city, Morocco.

The samples were characterized and then treated using alum, and Moringa Oleifera seeds extracts as single coagulants. The tests were carried out in the Laboratory of the National Office of Electricity and Drinking Water (ONEE), (Rabat, Morocco).

The results obtained from the treatment with seeds extract of Moringa Oleifera, especially at optimum dosage $250 \mathrm{mg} / \mathrm{L}$, were encouraging and revealed a removal efficiency of $95.5 \%$ TSS, $97.5 \%$ turbidity, $76.8 \%$ COD, $72 \%$ BOD according to Moroccan standards. When alum was used as a coagulant, the removal rates of $96.8 \%$ TSS, $98.1 \%$ turbidity, $81.8 \%$ COD, $75.5 \%$ BOD using the optimum dose of 150 $\mathrm{mg} / \mathrm{L}$. According to these results can be recommended the use of M. Oleifera seeds extracts (MOSE) as a coagulant in the treatment of domestic wastewater. Thus, the extracts of M. Oleifera seeds to be a suitable alternative for commercial alum in water treatment technology in the nearest future.

\section{References}

1. B. Adelodun, M. S. Ogunshina, F. O. Ajibade, T. S. Abdulkadir, H. O. Bakare, et K. S. Choi, Water, 12(7), 14 (2020).

2. P. Vega Andrade, C. F. Palanca, M. A. C. de Oliveira, C. Y. K. Ito, et A. G. dos Reis, J. Water Process Eng., 11 (2020).
3. N. A. Jadabi, M. Laaouan, J. Mabrouki, et S. E. Hajjaji, J. Adv. Res. Dyn. Control Syst., 12(7), 147-157 (2020).

4. E. Vunain, E. F. Masoamphambe, P. M. G. Mpeketula, M. Monjerezi, et A. Etale, J. Environ. Chem. Eng., 7(3), 8 ( 2019).

5. E. N. Ali, S. A. Muyibi, H. M. Salleh, Z. Alam, et M. R. M. Salleh, Fourteenth Int. Water Technol. Conf. IWTC 14 Cairo Egypt, 95-102 (2010).

6. N. Ueda Yamaguchi et al., Process Saf. Environ. Prot., 147, 405-420 (2021).

7. J. Mabrouki, A. Moufti, I. Bencheikh, K. Azoulay, Y. El Hamdouni, et S. El Hajjaji, in Advanced Intelligent Systems for Sustainable Development (AI2SD'2019), Cham, 200-212 (2020).

8. M. Megersa, A. Beyene, A. Ambelu, et L. Triest, Int. J. Environ. Sci. Technol., 16(5), 2333-2342 (2019).

9. A. L. Ahmad, S. Sumathi, et B. H. Hameed, Chem. Eng. J., 118(1-2), 99-105 (2006).

10. E. S. Elmolla, W. Hamdy, S. Mansour, et M. Boktor, Int. J. Environ. Res., 11 (2020).

11. A. F. S. Santos, A. C. C. Argolo, L. C. B. B. Coelho, et P. M. G. Paiva, Water Res., 39(6), 975-980 (2005).

12. S. Gautam et G. Saini, Glob. J. Environ. Sci. Manag., 6(4), 553-578 (2020).

13. A. F. Attah et al., South Afr. J. Bot., 8 (2019).

14. A. C. S. Nascimento, A. F. G. de Oliveira, M. B. de Lavôr, E. C. Pereira, et M. C. C. de Amorim, Rev. Eletrônica Em Gest. Educ. E Tecnol. Ambient., 24, 15. (2020).

15. A. Ndabigengesere, K. S. Narasiah, et B. G. Talbot, Water Res., 29(2), 703-710 (1995).

16. A. H. Jagaba et I. M. Lawal, Int. J. Eng. Manag., 2(3), 67-75 (2018).

17. P.-H. Chuang, C.-W. Lee, J.-Y. Chou, M. Murugan, B.-J. Shieh, et H.-M. Chen, Bioresour. Technol., 98, 232-236 (2007).

18. B. A. Nordmark, T. M. Przybycien, et R. D. Tilton, J. Environ. Chem. Eng., 4(4) 4690-4698 (2016).

19. P. Egbuikwem et A. Sangodoyin, Eur. Int. J. Sci. Technol., 2(7), 13-20 (2013).

20. M. S. Jami, N. S. Zakaria, M. Ahmed, N. R. N. A. Ghani, M. Ngabura, et M. M. Ahmad, IIUM Eng. J., 21(2), 12-24 (2020).

21. T. Okuda, A. U. Baes, W. Nishijima, et M. Okada, Water Res., 33(15), 3373-3378 (1999).

22. S. K. Kansal et A. Kumari, Chem. Rev., 114(9), 4993-5010 (2014).

23. D. L. Villaseñor-Basulto, P. D. Astudillo-Sánchez, J. del Real-Olvera, et E. R. Bandala, J. Water Process Eng., 23, 151-164 (2018).

24. R. A. Kwabena Ntibrey, F. A. Kuranchie, et S. F. Gyasi, Heliyon, 6(8), 10 (2020).

25. A. Q. Zaid, S. B. Ghazali, N. S. A. Mutamim, et O. A. Olalere, SN Appl. Sci., 1(5), 5 (2019).

26. M. Dehghani et M. H. Alizadeh, Environ. Health Eng. Manag., 3(4), 225-230 ( 2016). 
27. Andresa C. Feihrmann, Aline T.A. Baptista, Joao P. Lazari, Mariana O. Silva, Marcelo F. Vieira, et Angelica M.S. Vieira, Chem. Eng. Trans., 57, 1543-1548 ( 2017).

28. O. A. Adesina, F. Abdulkareem, A. S. Yusuff, M. Lala, et A. Okewale, South Afr. J. Chem. Eng., 28, 46-51 (2019).

29. M. Mageshkumar et R. Karthikeyan, Desalination Water Treat., 57, 1-11 (2015).

30. S. M. A. Basra, Z. Iqbal, Khalil-ur-Rehman, Hafeez-Ur-Rehman, et M. F. Ejaz, J. Appl. Res. Technol., 12(3), 560-567 (2014).
31. C. A. Igwegbe, O. D. Onukwuli, J. O. Ighalo, et M. C. Menkiti, Curr. Res. Green Sustain. Chem., 4, 44 (2021).

32. J. O. Ighalo et O. A. A. Eletta, Chem. Eng. Commun., 1-12, (2020).

33. J. O. Ighalo et A. Adeniyi, Appl. Sci., 2, 16 (2020).

34. M. A. Hubbe et O. J. Rojas, BioResources, 3(4), 1419-1491 (2008).

35. R. Katalo, T. Okuda, L. D. Nghiem, et T. Fujioka, Environ. Sci. Water Res. Technol.,4(10), 1604-1611 (2018). 